\title{
Selection of Lactic Acid Bacteria Isolated from San Simón da Costa Cheese (PD0) in Order to Develop an Autochthonous Starter Culture
}

\author{
Leticia González¹, Araceli Fernández Cuadrillero, José María Castro², Ana Bernardo', \\ María Eugenia Tornadijo ${ }^{{ }^{*}}$ \\ ${ }^{1}$ Department of Food Hygiene and Technology, University of León, León, Spain \\ ${ }^{2}$ Institute of Food Science and Technology (ICTAL), University of León, León, Spain \\ Email: ${ }^{*}$ metorr@unileon.es
}

Received 12 September 2015; accepted 24 October 2015; published 27 October 2015

Copyright (C) 2015 by authors and Scientific Research Publishing Inc.

This work is licensed under the Creative Commons Attribution International License (CC BY). http://creativecommons.org/licenses/by/4.0/

c) (i) Open Access

\begin{abstract}
Traditional cheeses are an important reservoir of microbial diversity that can have important biotechnological applications, especially with a view to improving the characteristics unique to each type of cheese, and in this respect, starter cultures consisting of autochthonous lactic acid bacteria strains are of particular interest. In the present study, we investigated lactic acid bacteria population diversity in San Simón da Costa cheese (PDO, Galicia, Spain) and found a predominance of the genus Lactobacillus, which by the end of ripening accounted for $78 \%$ of the strains isolated in Rogosa agar, around 40\% of those in M17 agar and about 10\% of those in MSE agar. The main species of lactic acid bacteria identified were Lactococcus lactis subsp. lactis, Lactobacillus casei subsp. casei, Lb. paracasei subsp. paracasei, Leuconostoc mesenteroides and Enterococcus faecalis. Virtually all the strains studied from a technological point of view yielded more than or equal to $0.24 \mathrm{~g} 100 \mathrm{~mL}^{-1}$ lactic acid. Lactococcus lactis subsp. lactis (SS 194), Lactobacillus paracasei (SS 1695 and SS 1689) and Enterococcus faecalis (SS 1378 and SS 1449) strains exhibited the greatest proteolytic capacity. Based on the overall technological aptitude of the tested strains, we can propose starter cultures and co-cultures that include different combinations of previous strains with a view to manufacturing San Simón da Costa cheese from pasteurised milk.
\end{abstract}

\section{Keywords}

Cow Milk Cheese, Lactic Acid Bacteria, Enzymatic Activities, Autochthonous Starter

\footnotetext{
${ }^{*}$ Corresponding author.
}

How to cite this paper: González, L., Fernández Cuadrillero, A., Castro, J.M., Bernardo, A. and Tornadijo, M.E. (2015) Selection of Lactic Acid Bacteria Isolated from San Simón da Costa Cheese (PDO) in Order to Develop an Autochthonous Starter Culture. Advances in Microbiology, 5, 748-759. http://dx.doi.org/10.4236/aim.2015.511079 


\section{Introduction}

San Simón da Costa cheese is a protected designation of origin (PDO) cheese manufactured in Galicia (Spain). It is made in the region of A Terra Chá, which encompasses several municipalities in the province of Lugo (Galicia, Spain). San Simón da Costa is a matured cheese made with full fat cow’s milk without colostrum or preservatives and with a balanced composition of fat and protein, in accordance with the characteristics of the breeds of origin and the season of the year, so that the final product has a $45 \%$ fat content in dry matter. It is a semi-hard, semi-elastic cheese with a few small eyes, which has a conical pear shape and a honey-coloured, waxy rind. The smell is slightly acid, although the smell of smoke predominates once matured because processing includes a stage of smoking.

A determining factor in the development of the textures and organoleptic characteristics of cheeses is the enzymatic potential of the strains used as starter cultures in cheese manufacture. Lactic cultures play a crucial role at the beginning of fermentation, developing acidity and favouring coagulation. In addition, they are involved in ripening and development of the aroma of the cheeses [1] [2]. Non-starter lactic acid bacteria (NSLAB) also have a strong influence on the development of the flavour, aroma and texture of cheeses and therefore, on their quality [3].

Some microorganisms present enzymatic activities that allow them to survive in the gastrointestinal tract and/or prevent colonisation of the same by potential pathogens, improving the digestibility of certain foods and/or modulating the immune system of the host [4] [5].

The study of the microbiota of artisanal cheeses makes possible to select autochthonous lactic acid bacteria for the production of starter cultures that present a good capacity for adaptation in fermented dairy products and which can be used at an industrial level to obtain cheeses presenting organoleptic characteristics similar to those of artisanal cheeses.

In previous research, we focused on Enterobacteriaceae, Enterococcus and Micrococcus groups isolated during the manufacture and ripening of San Simón da Costa cheese [6]-[8]. In the present study, we focused on the lactic acid bacteria population in San Simón da Costa cheese, with two objectives: to determine the most representative species which may exercise a predominant role in the ripening process of this cheese, and depending on their technological capacity, to select those strains best suited to form part of a starter or adjunct culture that could be used in the industrial manufacture of this cheese.

\section{Material and Methods}

\subsection{Cheese Manufacture and Sampling}

Four batches of cheese were manufactured for this study by cheese artisans according to the traditional manufacturing procedure described in García et al. (2001) [7].

Full fat untreated cow's milk was heated to approximately $30^{\circ} \mathrm{C}$, and the milk was then salted using $10-20 \mathrm{~g}$ salt per litre of milk. The milk was coagulated at $30^{\circ} \mathrm{C}-32^{\circ} \mathrm{C}$ by adding $100 \mathrm{~mL}$ of commercial calf rennet (strength 1:10,000) for every $100 \mathrm{~L}$ of milk. Thirty min after the addition of rennet, the curd was cut to obtain pieces measuring 5 - $12 \mathrm{~mm}$ in diameter. After leaving the cut curds to rest for a period of 5 to $10 \mathrm{~min}$, they were washed and the first manual pressing was performed, gently pressing the curds without removing them from the container until a well-drained homogeneous mass formed at the bottom of the container. Approximately $25 \%$ of the volume of the whey was removed and the pressed curd was scalded with approximately the same volume of hot water as the separated whey. When the curd was well-compacted, the whey was drained, and the curd was pre-pressed and transferred into conical moulds. Pressing was initially performed using a pressure of 1 $\mathrm{Kg} \cdot \mathrm{cm}^{-2}$, which was increased by the same amount every hour for a total of $3 \mathrm{~h}$. Then, the cheeses were removed from the moulds and scalded. The cheeses were ripened at a temperature of $10^{\circ} \mathrm{C}-12^{\circ} \mathrm{C}$ and a relative humidity of $70 \%$ - 80\%, for 45 - 60 days. The final step before sale was to smoke the cheese.

Samples were collected of milk, curd and cheese at 1, 2, 4 and 6 weeks of ripening. All samples were taken to the laboratory under refrigeration and analysed upon arrival.

\subsection{Microbiological Analysis}

Fifty g of milk, curd and core samples of the cheeses at different stages of ripening were collected aseptically and homogenised with $200 \mathrm{~mL}$ of a sterile $2 \%$ solution of tribasic sodium citrate at $40^{\circ} \mathrm{C}-45^{\circ} \mathrm{C}$ for $2 \mathrm{~min}$ in a 
Sorvall Homogeniser model 17,106. A 1/5 solution was obtained, which was used to prepare successive decimal solutions by mixing $10 \mathrm{~mL}$ of the stock solution with $90 \mathrm{~mL}$ of $0.1 \%$ sterile peptone, according to International Dairy Federation (IDF) Standard 122B (1992).

Different media were employed depending on their selectivity for enumeration and isolation of lactic acid bacteria. MSE agar (Biokar Diagnostics, Beavais, France), is one of the most frequently used media culture for count and isolation of Leuconostoc, after incubation at $22^{\circ} \mathrm{C}$ for 4 days [9]. It is a medium with a very high concentration of sucrose (10\%) which promotes the presence of mucoid colonies by dextrane producing strains. In addition it contains sodium azide, a known inhibitor of Gram negative bacteria and partially inhibitor of the lactococci as well. The rich complex medium M17 agar (Biokar Diagnostics, Beavais, France) promotes the growth of Lactococcus, especially those with complex nutrient requirements, after incubation at $30^{\circ} \mathrm{C}$ for 18 to $24 \mathrm{~h}$ [10]. The medium includes among others ingredients lactose (5\%) and sodium glycerophosphate (19\%) which increases the buffering capacity. Rogosa agar (Oxoid, Basingstoke, UK) is an acidic medium (approximately 5.4) used for enumeration and isolation of Lactobacillus, after incubation at $30^{\circ} \mathrm{C}$ for 5 days [11]. This medium includes sodium acetate as one of the ingredients and small amounts of $\mathrm{Mn}, \mathrm{Mg}$ and Fe which stimulate the growth of lactobacilli. With the M17 and MSE agar plates, the surfaces were inoculated with $0.1 \mathrm{~mL}$ of each solution, while with the Rogosa agar plates, the mass itself was inoculated with $1 \mathrm{~mL}$, and after the agar had solidified, a cover of the same medium was added to generate conditions that favoured the growth of lactobacilli. Enumeration was performed on plates with between 30 and 300 colonies. The counts were expressed as colony forming units per gram or millilitre (cfu/g or $\mathrm{mL}$ ).

\subsection{Isolation and Identification of Strains}

Nine strains were randomly isolated from the samples of milk, curd and cheese core at different stages of ripening, in the M17 agar, MSE agar and Rogosa agar, a total of 216 strains for each culture medium. The 648 strains were purified by means of growing alternate subcultures in MRS agar and broth [12], and then stored at $-30^{\circ} \mathrm{C}$ with $20 \%$ glycerol. The strains were revived in MRS broth and subjected to the various tests described below, in order to identify them at genus level and subsequently at species level.

The tests performed for genus identification included Gram staining and observation of morphology, as well as the catalase test, production of $\mathrm{CO}_{2}$ from glucose, deamination of amino acid L-arginine, growth at $10^{\circ} \mathrm{C}$ and $45^{\circ} \mathrm{C}$ and growth in the presence of $6.5 \% \mathrm{NaCl}$.

Species identification was performed by means of different tests depending on the genus in question [13] [14].

The tests performed for assignment to a Lactococcus species included growth at $45^{\circ} \mathrm{C}, 40^{\circ} \mathrm{C}$ and $10^{\circ} \mathrm{C}$, the capacity for deamination of L-arginine, the capacity for production of diacetyl, the Voges-Proskauer test, growth in the presence of $4 \%$ and $6.5 \% \mathrm{NaCl}$ and the capacity for fermentation of various sugars (arabinose, xylose, sucrose, trehalose, mannitol, salicin, raffinose, inulin, glycerol, sorbitol, rhamnose, ribose and maltose).

Tests for the identification of Leuconostoc species included the capacity to grow at $37^{\circ} \mathrm{C}$, in the presence of $6.5 \% \mathrm{NaCl}$ and in the presence of $10 \%$ ethanol, as well as the capacity for production of dextran and fermentation of sugars (arabinose, cellobiose, fructose, glucose, lactose, maltose, melibiose, sucrose, salicin, and trehalose).

Homofermentative Lactobacillus species were identified by performing the following tests: growth at $45^{\circ} \mathrm{C}$ and the capacity for deamination of L-arginine and fermentation of sugars (lactose, arabinose, melibiose, sucrose, sorbitol, xylose, raffinose, rhamnose, inulin and sorbose). Heterofermentative Lactobacillus strains were identified according to growth at $15^{\circ} \mathrm{C}$ and $45^{\circ} \mathrm{C}$ and the capacity for deamination of L-arginine and fermentation of sugars (arabinose, cellobiose, lactose, melezitose, melibiose, raffinose, salicin, trehalose, xylose and mannose).

Tests for the identification of Enterococcus species were based on growth in the presence of $0.1 \%$ methylene blue, deamination of L-arginine, growth in the presence of $0.4 \%$ potassium tellurite, growth in KF agar, growth at $45^{\circ} \mathrm{C}$ and $50^{\circ} \mathrm{C}$ and fermentation of sugars (arabinose, melezitose, melibiose, sorbitol, rhamnose, raffinose, starch and sucrose).

\subsection{Genetic Characterisation}

Genetic characterisation was performed in order to confirm the identification obtained using classical methodology. DNA was extracted from the strains using the procedure described by O'Sullivan et al. (1993) [15] with some modifications. Polymerase chain reaction (PCR) amplification and DNA sequence analysis were performed following the methodology described by González et al. (2007) [16]. 


\subsection{Technological Characterisation}

The acidifying activity of the strains was determined in accordance with IDF Standard 306 (IDF, 1995). The strains were revived in MRS broth at $30^{\circ} \mathrm{C}$ for $24 \mathrm{~h}$. The microbial culture was inoculated in a proportion of 1 $\mathrm{mL}$ per $100 \mathrm{~mL}$ of $10 \%$ reconstituted skimmed milk.

Titratable acidity (TA) and $\mathrm{pH}$ were determined after 6,12 and $24 \mathrm{~h}$ of incubation at $30^{\circ} \mathrm{C}$.

The proteolytic activity of the strains was determined by spectrophotometry using the O-phthaldialdehyde derivatisation method [17]. The results were expressed in $\mathrm{mMGly} \cdot \mathrm{L}^{-1}$ of milk.

The enzymatic activity of the strains was evaluated by means of the API-ZYM test (BioMérieux, MarcyL'Étoile, France). Leuconostoc and Lactobacillus strains were incubated in MRS broth, and Lactococcus strains were incubated in Elliker broth for $16 \mathrm{~h}$ at $30^{\circ} \mathrm{C}$. The cultures were centrifuged at $7000 \mathrm{~g}$ for $15 \mathrm{~min}$ at $4^{\circ} \mathrm{C}$, and the sediment was resuspended in $2 \mathrm{~mL}$ phosphate buffer $(50 \mathrm{mM}, \mathrm{pH}$ 7) until attaining an optical density of between 5 and 6 on the McFarland scale, and $65 \mu \mathrm{L}$ was then inoculated in the API-ZYM strip microtubes. The API-ZYM strips were incubated at $37^{\circ} \mathrm{C}$ for $4 \mathrm{~h}$, and enzyme activity was scored from 0 to 5 by comparison of the colour developed at 5 min with the API-ZYM test colour reaction chart. The enzymatic activities examined included: alkaline phosphatase, esterase (C4), lipase esterase (C8), lipase (C14), leucinearylamidase, valinearylamidase, cystine-arylamidase, trypsin, $\alpha$-chymotrypsin, acid phosphatase, naphthol-AS-BI-phosphohydrolase, $\alpha$-galactosidase, $\beta$-galactosidase, $\beta$-glucuronidase, $\alpha$-glucosidase, $\beta$-glucosidase, and $\mathrm{N}$-acetyl- $\beta$-glucosaminidase.

\section{Results and Discussion}

\subsection{Identification of the Lactic Acid Bacteria}

From the strains isolated in the three culture media, $76.39 \%$ were identified as lactic acid bacteria at the genus and species level. A proportion of 28.48\% were isolated in M17 agar, 33.74\% in MSE agar and 37.78\% in Rogosa agar. Table 1 shows the genera isolated from M17 agar, MSE agar and Rogosa agar during the ripening of San Simón cheese.

Table 1. Changes in the genera isolated from M17 agar, MSE agar and Rogosa agar during the manufacture and ripening of San Simón cheese ${ }^{\mathrm{a}}$.

\begin{tabular}{|c|c|c|c|c|c|c|c|c|c|c|c|c|c|}
\hline \multirow{3}{*}{ Medium } & \multirow{3}{*}{ Genera } & \multirow[b]{2}{*}{ Milk } & & & & \multicolumn{8}{|c|}{ Ripening time (weeks) } \\
\hline & & & \multicolumn{3}{|c|}{ Curd } & \multicolumn{4}{|c|}{2} & \multicolumn{2}{|l|}{4} & \multicolumn{2}{|l|}{6} \\
\hline & & $\mathrm{N}^{\circ}$ cepas & (\%) & $\mathrm{N}^{\circ}$ cepas & $(\%)$ & $\mathrm{N}^{\circ}$ cepas & $(\%)$ & $\mathrm{N}^{\circ}$ cepas & $(\%)$ & $\mathrm{N}^{\circ}$ cepas & $(\%)$ & $\mathrm{N}^{\circ}$ cepas & \\
\hline \multirow{4}{*}{ M17 } & Lactococcus & --- & & 2 & 5.6 & 1 & 2.8 & 1 & 2.8 & 1 & 2.8 & 3 & 8.3 \\
\hline & Lactobacillus & 2 & 5.6 & 2 & 5.6 & 3 & 8.3 & 4 & 11.1 & 3 & 8.3 & 12 & 33.3 \\
\hline & Leuconostoc & --- & & --- & & 2 & 5.6 & --- & & 1 & 2.8 & 1 & 2.8 \\
\hline & Enterococcus & --- & & 5 & 13.9 & 2 & 5.6 & 9 & 25 & 6 & 16.7 & 11 & 30.6 \\
\hline \multirow{4}{*}{ MSE } & Lactococcus & 1 & 2.8 & 1 & 2.8 & 4 & 11.1 & 6 & 16.7 & 1 & 2.8 & 4 & 11.1 \\
\hline & Lactobacillus & 3 & 8.3 & 1 & 2.8 & 1 & 2.8 & 2 & 5.6 & 1 & 2.8 & 2 & 5.6 \\
\hline & Leuconostoc & 1 & 2.8 & 1 & 2.8 & 8 & 22.2 & 9 & 25 & 15 & 41.7 & 5 & 13.9 \\
\hline & Enterococcus & 9 & 25 & 9 & 25 & 14 & 38.9 & 9 & 25 & 12 & 33.3 & 16 & 44.4 \\
\hline \multirow{4}{*}{ ROGOSA } & Lactococcus & -- & & 1 & 2.8 & --- & & --- & & 5 & 13.9 & 3 & 8.3 \\
\hline & Lactobacillus & 22 & 61.1 & 16 & 44.4 & 24 & 66.6 & 19 & 52.8 & 18 & 50 & 28 & 77.8 \\
\hline & Leuconostoc & 2 & 5.6 & 1 & 2.8 & 1 & 2.8 & 1 & 2.8 & 3 & 8.3 & 2 & 5.6 \\
\hline & Enterococcus & 2 & 5.6 & 3 & 8.3 & 3 & 8.3 & 4 & 11.1 & 10 & 27.8 & 3 & 8.3 \\
\hline
\end{tabular}

${ }^{\mathrm{a}}$ The percentage was calculated from the isolated strains in each sampling point and for the four batches (36 strains from each culture medium). 
The proportion of lactic acid bacteria strains assigned to the genus Lactococcus was $9.29 \%$. In this study, the M17 agar showed poor selectivity for the isolation of lactococci since only 3.75\% of the strains isolated in this medium were assigned to this genus. The lactococci strains were identified as Lactococcus lactis subsp. lactis (28.26\%), L. lactis subsp. cremoris (65.22\%) and L. lactis subsp. raffinolactis (4.35\%).

In most Spanish artisanal cheeses, L. lactis subsp. lactis constitutes the dominant species of the genus Lactococcus, whereas $L$. cremoris is only isolated on rare occasions [16] [18] [19].

Of the lactic acid bacteria strains, the $15.35 \%$ were identified as Leuconostoc. The MSE medium showed poor selectivity for the isolation of Leuconostoc. The strains of this genus were assigned to the species Ln. paramesenteroides (55.26\%), Ln. lactis (17.10\%), Ln. mesenteroides subsp. mesenteroides (6.58\%), Ln. cremoris (3.95\%) and Ln. mesenteroides subsp. dextranicum (1.31\%).

A proportion of $47.07 \%$ of the lactic acid bacteria strains were assigned to the genus Lactobacillus. This genus was isolated in Rogosa agar (58.80\%), in M17 agar (30.47\%) and in MSE agar (10.73\%). Therefore, the Rogosa agar showed high selectivity for the isolation of lactobacilli. Although homofermentative lactobacilli predominated (60.52\%), heterofermentative lactobacilli were also identified (39.48\%). López and Mayo (1997) [20] also detected a percentage of heterofermentative lactobacilli in studies conducted on several artisanal cheeses from Asturias.

The homofermentative lactobacilli strains isolated from San Simón cheese comprised $L b$. plantarum (10.30\% of the total lactobacilli), Lb. casei subsp. casei and $L b$. paracasei subsp. paracasei (34.76\%), Lb. rhamnosus (14.16\%) and $L b$. paracasei subsp. tolerans (1.29\%), while the heterofermentative strains included $L b$. buchneri (18.88\%), Lb. bifermentans (16.31\%) and Lb. fermentum (4.29\%).

Lactobacilli form part of the non-starter lactic acid bacteria (NSLAB) that contribute to the development of the final flavour of ripened cheeses. It is of interest, therefore, to select lactobacilli strains with technological aptitudes that contribute to improving the intensity and quality of a cheese's flavour and texture. In this regard, it should be noted that heterofermentative lactobacilli are seldom included as co-cultures in assays conducted with non-starter strains since they may cause defects in the cheese [21].

Lastly, 28.28\% of the strains isolated in the three culture media belonged to the genus Enterococcus. Of the enterococci, 70\% were ascribed to the species Enterococcus faecalis. García et al. (2002) [8] ascribed between $63 \%$ and $79 \%$ of the strains from milk, curd and San Simón cheese core, isolated in KAA agar, to the genus Enterococcus, the dominant species again being $E$. faecalis. Similar results were obtained in other varieties of cheese made with milk from different species and presenting very different characteristics, such as Roquefort cheese [22], Manchego cheese [23], Armada cheese [6], Roncal and Idiazabal cheese [24] and Tenerife cheese [25].

This biodiversity of species, and in particular the presence of $L b$. paracasei, Lc. lactis, Ln. mesenteroides and $E$. faecalis, has been also detected in a wide range of cheeses, and $L b$. paracasei has also presented a notable phenotypic diversity [26].

We selected 20 strains of lactic acid bacteria that had been identified at species level by classical methods and obtained from different batches and sampling points, which were representative of the majority of the biochemical patterns found, in order to verify their assignment to species by genetic methods. Figure 1 and Figure 2 show the electrophoresis images of the PCR products of lactic acid bacteria strains. In all cases, a single DNA band, of $834 \mathrm{pb}$, was obtained, the result of the PCR amplification of DNA that codes for 16S ribosomal RNA. The corresponding band was sequenced and compared with sequences deposited in databases. For some strains, it was possible to confirm the identification using classical methods. Identification of strains using classical methodology and molecular techniques yielded $100 \%$ agreement for the strains Lactococcus lactis subsp. lactis, Lactobacillus casei subsp. casei, Lactobacillus casei subsp. rhamnosus and Leuconostoc mesenteroides. However, 7 strains assigned to the species Lactobacillus casei by classical methodology were identified as Lactobacillus paracasei by genetic techniques. Lastly, it should be noted that with regard to Enterococcus faecalis, assignment coincided by $67 \%$.

Artisanal cheeses are an important reservoir of phenotypic and genotypic microbial diversity that can have important applications in biotechnology [27]-[29]. In fact, there is a growing interest in gaining a better knowledge of the microbiota of cheeses made with raw milk because of the need to find starter cultures that could complement or renew existing ones [30] [31].

\subsection{Technological Aptitude and Enzymatic Characteristics of the Lactic Acid Bacteria}

As reported above, 20 strains of lactic acid bacteria whose identification had been confirmed by molecular tech- 


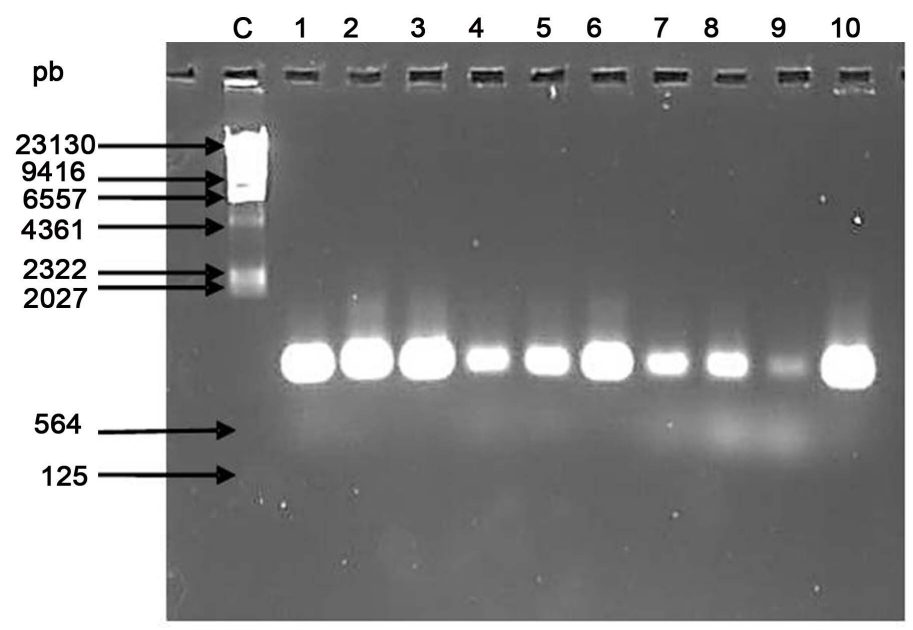

Figure 1. Electrophoresis of PCR products obtained with the 8 and 806 primers. C: Control. DNA of Lambda phage digested with Hind III. Order of 1 - 10: lactic acid strains isolated from artisanal San Simón cheese: Lactobacillus plantarum (SS 1239), Lactococcus lactis subsp. lactis (SS 13), Enterococcus faecalis (SS 26), Lactococcus lactis subsp. lactis (SS 193), Lactococcus lactis subsp. lactis (SS 194), Leuconostoc mesenteroides (SS 1437), strain not assigned to a genus (SS 1439), Lactococcus lactis subsp. lactis (SS 2379), Enterococcus sulphureus (SS 163), Leuconostoc pseudomesenteroides (SS 2068).

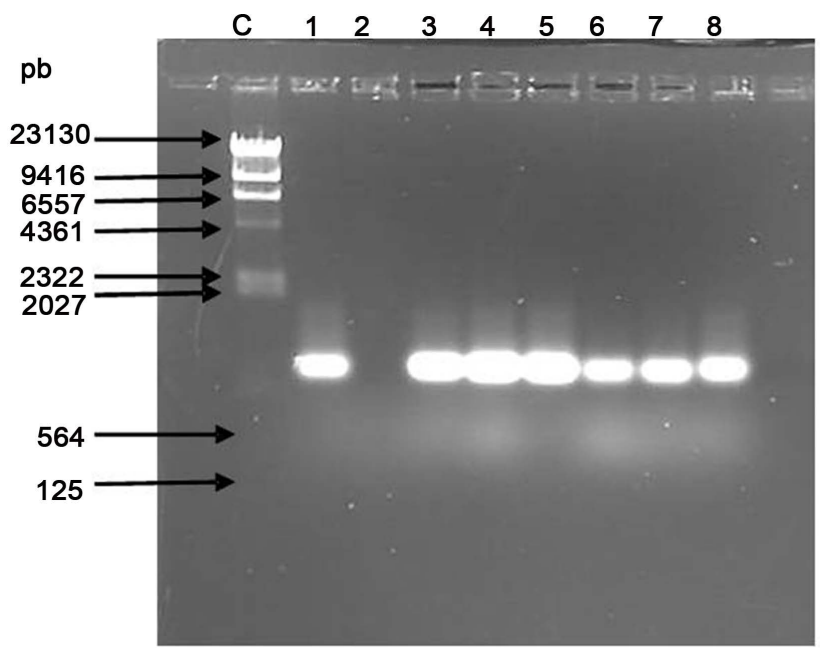

Figure 2. Electrophoresis of PCR products obtained with the 8-806 primer. C: Control. DNA of Lambda phage digested with Hind III. Order of 1-8: Lactobacillus casei (SS 1615), negative control without DNA, Lactobacillus plantarum (SS 1594), Lactobacillus casei (SS 263), Enterococcus raffinosus (SS 1293), Lactobacillus casei (SS 1614), Lactococcus lactis subsp. lactis (SS 2363), Enterococcus spp. (SS 164).

niques were selected in order to perform a technological aptitude study. The strains selected for study were as follows: Lactococcus lactis subsp. lactis (3 strains), Lactobacillus casei subsp. casei (3 strains), Lb. paracasei (7 strains), Lb. casei subsp. rhamnosus (1 strain), Leuconostoc mesenteroides (3 strains) and Enterococcus faecalis (3 strains).

One of the most important properties of the lactic acid bacteria that are used as starters in cheese making is their initial capacity to acidify milk [32]. In fact, in order for a lactic strain to be considered a good candidate for inclusion as a starter, it should produce sufficient acid to reduce the $\mathrm{pH}$ of the milk to values lower than 5.3 after $6 \mathrm{~h}$ of incubation in milk at $30^{\circ} \mathrm{C}$ [33]. Various authors agree that the difference between strains with a fast or slow acidifying capacity is that with the former, acidity increases within $6 \mathrm{~h}$ by up to at least $30^{\circ} \mathrm{C}[34]$-[36]. 
The acidifying capacity of the 20 strains of lactic acid bacteria tested was determined after 6,12 and $24 \mathrm{~h}$ of incubation at $30^{\circ} \mathrm{C}$. The results are shown in Table 2 .

Of the total number of strains tested, only 5 had the capacity to reduce milk pH to values lower than 6 after 6 hours of incubation at $30^{\circ} \mathrm{C}$, and 8 strains yielded a titratable acidity in milk equal to or greater than $30^{\circ} \mathrm{C}$, so in general can be considered slightly acidifying strains. These results are consistent with those previously obtained by other authors for other traditional cheeses [37] [38]. In general, the acidifying capacity of the strains belonging to Lactococcus lactis species was similar or slightly superior to that of the Lactobacillus and Leuconostoc strains, although there were variations in acidity production between strains of these species. These differences became more marked over the course of incubation, with values ranging from 0.39 to $0.85 \mathrm{~g} 100 \mathrm{~mL}^{-1}$ lactic acid, depending on the strain. The final acidification produced by some strains of lactobacilli and enterococci was higher than that yielded by Lactococcus and Leuconostoc strains, reaching values of around 0.75 - $0.85 \mathrm{~g} 100$ $\mathrm{mL}^{-1}$ lactic acid at $24 \mathrm{~h}$ of incubation, a behaviour which was also observed by Herreros et al. (2003) [39].

The results obtained for the proteolytic activity of the 20 selected strains are shown in Table 3. Both Leuconostoc and Lactococcus strains presented low proteolytic activity in general, with the former presenting the lowest activity, yielding values that did not exceed $0.2 \mathrm{mMGly} \cdot \mathrm{L}^{-1}$, while values for the Lactococcus strains were below $0.5 \mathrm{mMGly} \cdot \mathrm{L}^{-1}$, with the exception of one Lactococcus lactis strain that presented values of 0.80 $\mathrm{mMGly} \cdot \mathrm{L}^{-1}$. These values differed between strains but were generally slightly lower than those detected by various authors for other strains of Lactococcus isolated from traditional cheeses of different origins [37] [39] [40], although they were similar to those detected by Mayo et al. (1990) [41]. The majority of the Lactobacillus strains presented a proteolytic activity of between 0.1 and $0.5 \mathrm{mMGly} \cdot \mathrm{L}^{-1}$, and one $L b$. paracasei strain yielded values of around $1.6 \mathrm{mMGly} \cdot \mathrm{L}^{-1}$. In the case of the Enterococcus strains, two of the three strains tested released high concentrations of amino groups $\left(1.3\right.$ and $\left.1.8 \mathrm{mMGly} \cdot \mathrm{L}^{-1}\right)$ in comparison with the rest of the strains. In the later stages of ripening, NSLAB population contributes to proteolysis and development of the aroma of the cheeses.

Table 2. Acidifying activity of the 20 strains of lactic acid bacteria isolated from San Simón cheese.

\begin{tabular}{|c|c|c|c|c|c|c|c|}
\hline \multirow{3}{*}{ Strain } & & \multicolumn{6}{|c|}{ Incubation time (h) } \\
\hline & & \multicolumn{2}{|r|}{$6 \mathrm{~h}$} & \multicolumn{2}{|c|}{$12 \mathrm{~h}$} & \multicolumn{2}{|r|}{$24 \mathrm{~h}$} \\
\hline & & $\mathbf{p H}$ & Titratable acidiy $^{\mathrm{a}}$ & pH & Titratable acidiy $^{a}$ & pH & Titratable acidiy ${ }^{\mathrm{a}}$ \\
\hline & SS 193 & 6.2 & 0.32 & 5.6 & 0.44 & 4.84 & 0.64 \\
\hline \multirow[t]{3}{*}{ Lactococcus lactis } & SS 194 & 5.64 & 0.26 & 5.25 & 0.4 & 4.71 & 0.58 \\
\hline & SS 287 & 5.7 & 0.32 & 5.25 & 0.38 & 5.03 & 0.52 \\
\hline & SS 1614 & 6.23 & 0.31 & 5.63 & 0.41 & 5.06 & 0.59 \\
\hline \multirow[t]{5}{*}{ Lactobacillus casei sub sp. casei } & SS 1615 & 6.16 & 0.24 & 5.59 & 0.29 & 4.52 & 0.85 \\
\hline & SS 263 & 6.29 & 0.31 & 5.99 & 0.42 & 4.86 & 0.67 \\
\hline & SS 1644 & 6.08 & 0.26 & 5.29 & 0.39 & 4.9 & 0.74 \\
\hline & SS 1661 & 6.08 & 0.29 & 5.77 & 0.3 & 5.15 & 0.51 \\
\hline & SS 1695 & 6.21 & 0.2 & 5.66 & 0.28 & 5.07 & 0.55 \\
\hline \multirow[t]{4}{*}{ Lactobacillus casei sub sp. paracasei } & SS 1689 & 6.15 & 0.27 & 5.89 & 0.29 & 5.78 & 0.39 \\
\hline & SS 1770 & 6.12 & 0.21 & 5.66 & 0.4 & 4.5 & 0.75 \\
\hline & SS 1778 & 6.11 & 0.19 & 5.64 & 0.35 & 4.34 & 0.84 \\
\hline & SS 1785 & 6.10 & 0.3 & 5.72 & 0.3 & 4.32 & 0.85 \\
\hline \multirow[t]{2}{*}{ Lactobacillus casei sub sp. rhamnosus } & SS 1684 & 5.83 & 0.24 & 5.38 & 0.3 & 5.26 & 0.39 \\
\hline & SS 1435 & 5.7 & 0.3 & 5.51 & 0.33 & 5.18 & 0.43 \\
\hline \multirow[t]{3}{*}{ Leuconostoc } & SS 1437 & 6.13 & 0.31 & 5.56 & 0.4 & 5.39 & 0.46 \\
\hline & SS 1464 & 6.12 & 0.28 & 5.83 & 0.33 & 5.62 & 0.4 \\
\hline & SS 1378 & 5.88 & 0.33 & 5.02 & 0.48 & 4.55 & 0.8 \\
\hline \multirow[t]{2}{*}{ Enterococcus } & SS 191 & 6.08 & 0.27 & 5.4 & 0.56 & 4.77 & 0.85 \\
\hline & SS 1449 & 6.18 & 0.25 & 5.68 & 0.3 & 5.44 & 0.4 \\
\hline
\end{tabular}

${ }^{\mathrm{a}}$ Titratable acidity expressed as g $100 \mathrm{~mL}^{-1}$ lactic acid. 
Table 3. Proteolytic activity of the 20 strains of lactic acid bacteria isolated from San Simón cheese.

\begin{tabular}{|c|c|c|}
\hline \multicolumn{2}{|l|}{ Strain } & \multirow{2}{*}{$\begin{array}{c}\text { Proteolytic activity }^{\mathrm{a}} \\
0.135 \pm 0.010\end{array}$} \\
\hline & SS 193 & \\
\hline \multirow[t]{3}{*}{ Lactococcus lactis } & SS 194 & $0.804 \pm 0.060$ \\
\hline & SS 287 & $0.398 \pm 0.020$ \\
\hline & SS 1614 & $0.505 \pm 0.018$ \\
\hline \multirow[t]{5}{*}{ Lactobacillus casei sub sp. casei } & SS 1615 & $0.182 \pm 0.012$ \\
\hline & SS 263 & $0.051 \pm 0.010$ \\
\hline & SS 1644 & $0.135 \pm 0.008$ \\
\hline & SS 1661 & $0.060 \pm 0.006$ \\
\hline & SS 1695 & $0.637 \pm 0.040$ \\
\hline \multirow[t]{4}{*}{ Lactobacillus casei sub sp. paracasei } & SS 1689 & $1.605 \pm 0.005$ \\
\hline & SS 1770 & $0.470 \pm 0.006$ \\
\hline & SS 1778 & $0.290 \pm 0.003$ \\
\hline & SS 1785 & $0.398 \pm 0.002$ \\
\hline \multirow[t]{2}{*}{ Lactobacillus casei sub sp. rhamnosus } & SS 1684 & $0.111 \pm 0.001$ \\
\hline & SS 1435 & $0.099 \pm 0.001$ \\
\hline \multirow[t]{3}{*}{ Leuconostoc } & SS 1437 & $0.195 \pm 0.003$ \\
\hline & SS 1464 & $0.132 \pm 0.005$ \\
\hline & SS 1378 & $1.832 \pm 0.006$ \\
\hline \multirow[t]{2}{*}{ Enterococcus } & SS 191 & $0.374 \pm 0.001$ \\
\hline & SS 1449 & $1.320 \pm 0.002$ \\
\hline
\end{tabular}

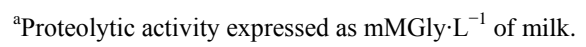

While some authors have related the proteolytic and acidifying activity of some lactic acid bacteria such as the lactococci [34] [41] [42], no such relationship was observed in the present study, and appeared rather as the characteristic properties of each strain.

The enzymatic activities of the 20 strains assessed by means of the API-ZYM system are shown in Table 4.

None of the microorganisms presented activities for the following enzymes: trypsin, $\beta$-glucuronidase, Nacetyl- $\beta$-glucosaminidase, $\alpha$-mannosidase and $\alpha$-fucosidase. Similar results have been reported for strains isolated from Arzúa-Ulloa cheese [43] and other artisanal cheeses [44]. In addition, the absence of some of these activities, for example $\beta$-glucuronidase, can be considered as being of a probiotic nature, since this enzyme increases the production of toxic and/or carcinogenic compounds [45]. A-chymotrypsin and trypsin activity showed low or null values. Bearing in mind that these may be involved in pathogenic processes, their absence is interesting from a probiotic point of view [46].

With respect to activity on the rest of the carbohydrates, most of the strains of the Lactobacillus and Leuconostoc genera showed high $\alpha$-glucosidase activity, but this was not detected in Lactococcus lactis strains and only minimal activity was observed in Enterococcus faecalis strains. This enzyme participates in the hydrolysis of the $\alpha(1-4)$ glucans, which cannot be degraded by human glucosidases; thus, the lactobacilli that showed this activity could be of probiotic interest. At the same time, it catalyses the final steps of carbohydrate digestion and therefore its absence slows the assimilation of carbohydrates ingested in the diet, and is therefore useful for obese or diabetic patients. In terms of $\beta$-galactosidase activity, some strains of lactobacilli showed high activity which could be related to the capacity to reduce lactose intolerance and stimulation of the growth of bifidobacteria in the intestine [44]. 
Table 4. Enzymatic activity ${ }^{\mathrm{a}}$ (API-ZYM) of lactic acid bacteria isolated from San Simón cheese.

\begin{tabular}{|c|c|c|c|c|c|c|c|c|c|c|c|c|c|c|c|c|c|c|c|}
\hline & \multirow[t]{2}{*}{ Strains } & \multicolumn{18}{|c|}{ Enzymes tested } \\
\hline & & 1 & 2 & 3 & 4 & 5 & 6 & 7 & 89 & 10 & 11 & 12 & 13 & 14 & 15 & 16 & 17 & 18 & 19 \\
\hline \multirow{3}{*}{ Lactococus lactis } & SS 193 & - & $5-10$ & 10 & - & 20 & - & 5 & -5 & 10 & 5 & - & - & - & - & - & - & - & - \\
\hline & SS 194 & - & 5 & 10 & - & 40 & 5 & 5 & -5 & 10 & 5 & - & - & - & - & - & - & - & - \\
\hline & SS 287 & - & $<5$ & $<5$ & - & 30 & - & - & - & 40 & 5 & - & - & - & - & - & - & - & - \\
\hline \multirow{3}{*}{$\begin{array}{c}\text { Lactobacillus } \\
\text { casei } \\
\text { subsp. casei }\end{array}$} & SS 1614 & - & $5-10$ & 10 & - & 40 & $10-20$ & - & $-<5$ & 5 & 10 & - & - & - & 20 & - & - & - & - \\
\hline & SS 1615 & - & $10-20$ & 20 & - & 40 & 40 & 20 & - & 5 & 20 & - & - & - & 20 & - & - & - & - \\
\hline & SS 263 & - & 20 & 30 & - & 40 & 40 & - & - & 10 & 20 & - & 10 & - & 40 & - & - & - & - \\
\hline \multirow{7}{*}{$\begin{array}{l}\text { Lactobacillus } \\
\text { casei sub } \\
\text { sp. paracasei }\end{array}$} & SS 1644 & - & 10 & 10 & - & $>40$ & $>40$ & 5 & -5 & 20 & 40 & - & 20 & - & $>40$ & 5 & - & - & - \\
\hline & SS 1661 & - & 20 & 20 & - & $\geq 40$ & $\geq 40$ & 5 & -5 & 20 & 30 & - & 30 & - & $\geq 40$ & 5 & - & - & - \\
\hline & SS 1695 & - & 10 & 10 & - & $>40$ & $>40$ & 5 & -5 & 20 & 30 & - & 20 & - & 30 & - & - & - & \\
\hline & SS 1689 & - & $10-20$ & 10 & - & 5 & - & - & - & 5 & 5 & - & - & - & - & - & - & - & - \\
\hline & SS 1770 & - & $10-20$ & $10-20$ & - & 40 & 20 & 10 & -5 & 10 & 20 & - & $<5$ & - & 10 & - & - & - & - \\
\hline & SS 1778 & - & 20 & 10 & $<5$ & 40 & 40 & 5 & -- & $5-10$ & 20 & - & $<5$ & - & $30-40$ & - & - & - & - \\
\hline & SS 1785 & - & $10-20$ & 10 & - & 40 & 40 & - & - & 5 & 20 & - & - & - & 40 & - & - & - & - \\
\hline \multirow[t]{2}{*}{$\begin{array}{c}\text { Lb. casei } \\
\text { sub sp. rhamnosus }\end{array}$} & SS 1684 & - & 10 & 10 & - & 30 & - & - & - & 20 & $30-40$ & - & $10-20$ & - & 40 & - & - & - & - \\
\hline & SS 1435 & - & $10-20$ & $5-10$ & - & 5 & - & - & -- & $5-10$ & 20 & 10 & $10-20$ & - & 40 & - & - & - & - \\
\hline \multirow[t]{3}{*}{ Leuconostoc } & SS 1437 & - & 10 & 10 & - & 20 & - & - & -- & 5 & 10 & - & - & - & - & - & - & - & - \\
\hline & SS 1464 & & - & - & - & 5 & - & - & - & 20 & - & 20 & 5 & - & $30-40$ & - & - & - & - \\
\hline & SS 1378 & - & 20 & 20 & - & 30 & - & 5 & - & 5 & - & - & 5 & - & - & - & - & - & - \\
\hline \multirow[t]{2}{*}{ Enteroccocus } & SS 191 & $<5$ & 20 & 5 & - & 30 & 5 & 10 & -20 & 20 & 5 & - & 5 & - & 5 & - & - & - & \\
\hline & SS 1449 & - & 20 & 10 & - & - & - & $0-5$ & -5 & 5 & 5 & - & - & - & - & $<5$ & - & - & - \\
\hline
\end{tabular}

${ }^{\mathrm{a}}$ Enzimatic activity (approximate values) expressed as nmol of substrate hydrolysed. ${ }^{\mathrm{b}}$ Enzimes tested: 1 . Alkaline phosphatase; 2 . Esterase (C4); 3. Esterase lipase (C8); 4. Lipase (C14); 5. Leucinearilamidasa; 6. Valina arilamidase. 7. Cistina arylamidasa; 8. Tripsin; 9. $\alpha$-Quimotrypsin; 10. Acidphosphatase; 11. Naphthol-AS-BI-phosphohydrolase; 12. $\alpha$-galactosidase; 13 . $\beta$-galactosidase; $14 . \beta$-glucuronidase; 15 . $\alpha$-glucosidase; 16 . $\beta$-glucosidase; 17 . N-acetyl- $\beta$-glucosaminidase; $18 . \alpha$-mannosidase; 19 . $\alpha$-fucosidase.

No alkaline phosphatase activity was detected in any of the strains tested, what appears to be common in the case of lactic acid bacteria [39] [47] [48]. In contrast, acid phosphatase activity, an enzyme necessary for hydrolysis of phosphopeptides, attained very variable values ranging from 5 to $20 \mathrm{nmol}$ of substrate hydrolysed, with the exception of one Lactococcuslactis strain which yielded values of $40 \mathrm{nmol}$. The high phosphatase activity exhibited by lactic acid bacteria strains may have an important application in the degradation of phytate.

Esterase and esterase-lipase activities were different depending on the groups and strains tested; in general, lactococci strains presented the lowest values while Enterococcus faecalis strains presented the highest values. None of the strains except for one showed any activity on long chain fatty acids, which confirms the fact that lactic acid bacteria show a preference for short-chain substrates.

Leucineaminopeptidase activity was detected in all strains, and elevated activity (in the order of $40 \mathrm{nmol}$ of hydrolysed substrate) was observed in the majority of the Lactobacillus casei strains, with levels comparable to those obtained by other authors. A high valineaminopeptidase activity was also observed in these strains, which was not detected in the rest of the tested strains. The presence of aminopeptidase activity is desirable since it can help generate the characteristic aroma of cheese and decrease bitterness by hydrolysing the peptides formed during cheese ripening. 


\section{Conclusion}

In conclusion, some of the lactic acid bacteria strains isolated from San Simón da Costa cheese may contribute to the acidification of milk and curd and to the formation of aromas and flavours as a consequence of their proteolytic and esterase-lipase activities. Two Lactococcus lactis subsp. lactis strains (SS 193 and SS 1437) could be selected to constitute a starter culture based on their acidifying capacity. One L. lactis subsp. lactis strain (SS 194) and two Lb. paracasei strains (SS 1689 and 1695 SS) were notable for their proteolytic capacity, and could be used as co-cultures. The proteolytic activity of Enterococcus strains 1378 SS and SS 1449 is also noteworthy.

\section{Acknowledgements}

The authors wish to express their gratitude to the cheese makers of A Terra Chá (Lugo, Galicia) for the manufacture of the cheeses and their contribution to this work.

\section{References}

[1] Castillo, I., Calvo, M.V., Alonso, L., Juárez, M. and Fontecha, J. (2007) Changes in Lipolysis and Volatile Fraction of a Goat Cheese Manufactured Employing a Hygienized Rennet Paste and Defined Strain Starter. Food Chemistry, 100, 590-598. http://dx.doi.org/10.1016/j.foodchem.2005.09.081

[2] Delgado, F.J., González-Crespo, J., Cava, R., García-Parra, J. and Ramírez, R. (2010) Characterization by SPME-GCMS of the Volatile Profile of a Spanish Soft Cheese P.D.O. Torta del Casar during Ripening. Food Chemistry, 118, 182-189. http://dx.doi.org/10.1016/j.foodchem.2009.04.081

[3] Sheehan, J.J., Wilkinson, M.G. and McSweeney, P.L.H. (2008) Influence of Processing and Ripening Parameters on Starter, Non-Starter and Propionic Acid Bacteria and on the Ripening Characteristics of Semi-Hard Cheeses. International Dairy Journal, 18, 905-917. http://dx.doi.org/10.1016/j.idairyj.2007.11.024

[4] Bergamini, C.V., Hynes, E.R., Palma, S.B., Sabbag, N.G. and Zalacar, C.A. (2009) Proteolytic Activity of Three Probiotic Strains in Semi-Hard Cheese as Single and Mixed Cultures: Lactobacillus acidophilus, Lactobacillus paracasei and Bifidobacterium lactis. International Dairy Journal, 19, 467-475. http://dx.doi.org/10.1016/j.idairyj.2009.02.008

[5] Ayeni, F.A., Sánchez, B., Adeniyi, B.A., De los Reyes Gavilán, C.G., Margolles, A. and Ruas-Madiedo, P. (2011) Evaluation of the Functional Potential of Weissella and Lactobacillus Isolates Obtained from Nigerian Traditional Fermented Foods and Cow's Intestine. International Journal of Food Microbiology, 147, 97-104. http://dx.doi.org/10.1016/j.ijfoodmicro.2011.03.014

[6] Tornadijo, M.E., Fresno, J.M., Bernardo, A., Martín Sarmiento, R. and Carballo, J. (1995) Microbiological Changes throughout the Manufacturing and Ripening of on Spanish Goat’s Raw Milk Cheese (Armada Variety). Le Lait, 75, 551-570. http://dx.doi.org/10.1051/lait:1995643

[7] García Fontán, M.C., Franco, I., Prieto, B., Tornadijo, M.E. and Carballo, J. (2001) Microbiological Changes in "San Simón” Cheese throughout Ripening and Its Relationship with Physico-Chemical Parameters. Food Microbiology, 18, 25-33. http://dx.doi.org/10.1006/fmic.2000.0351

[8] García Fontán, M.C., Rodríguez, M.J., Bernardo, A., Tornadijo, M.E. and Carballo, J. (2002) Study of Enterococci and Micrococci Isolated throughout Manufacture and Ripening of San Simón Cheese. Food Microbiology, 19, 23-33. http://dx.doi.org/10.1006/fmic.2001.0457

[9] Mayeux, J.V., Sandine, W.E. and Elliker, P.R. (1978) A Selective Medium for Detecting Leuconostoc Organism in Mixed-Strain Starter Cultures. Journal Dairy Science, 45, 655-656.

[10] Therzagui, B.E. and Sandine, W.E. (1975) Improved Medium for Lactic Streptococci and Their Bacteriophages. Applied in Microbiology, 29, 807-813.

[11] Rogosa, M., Mitchell, J.A. and Wiseman, R.F. (1951) A Selective Medium for the Isolation of Oral and Faecal Lactobacilli. Journal of Bacteriology, 62, 132-133.

[12] De Man, J.D., Rogosa, M. and Sharpe, M.E. (1960) A Medium for the Cultivation of Lactobacilli. Journal of Applied Bacteriology, 23, 130-135. http://dx.doi.org/10.1111/j.1365-2672.1960.tb00188.x

[13] Mundt, J.O. (1986) Enterococci. In: Sneath, P.H.A., Mair, N.S., Sharpe, M.E. and Holt, J.G., Eds., Bergey’s Manual of Systematic Bacteriology, Vol. 2, Williams \&Wilkins, Baltimore, 1063-1065.

[14] Garvie, E.I. (1986) Genus Leuconostoc. In: Sneath, P.H.A., Mair, N.S., Sharpe, M.E. and Holt, J.G., Eds., Bergey’s Manual of Systematic Bacteriology, The Williams and Wilkins Co., Baltimore.

[15] O'Sullivan, D.J. and Klaenhammer, T.R. (1993) Rapid Mini-Prep Isolation of High-Quality Plasmid DNA from Lactococcus and Lactobacillus spp. Applied and Environmental Microbiology, 59, 2730-2733. 
[16] González, L., Sandoval, H., Sacristán, N., Castro, J.M., Fresno, J.M. and Tornadijo, M.E. (2007) Identification of Lactic Acid Bacteria Isolated from Genestoso Cheese throughout Ripening and Study of Their Antimicrobial Activity. Food Control, 18, 716-722. http://dx.doi.org/10.1016/j.foodcont.2006.03.008

[17] Church, F.C., Swaisgood, H.E., Porter, D.H. and Catignani, G.L. (1983) Spectrophotometric Assay Using o-Phthaldialdehyde for Determination of Proteolysis in Milk and Isolated Milk Proteins. Journal of Dairy Science, 66, 1219-1227. http://dx.doi.org/10.3168/jds.S0022-0302(83)81926-2

[18] Cuesta, P., Fernández-García, E., González de llano, D., Montilla, A. and Rodríguez, A. (1996) Evolution of the Microbiological and Biochemical Characteristics of Afuega'l Pitu Cheese during Ripening. Journal of Dairy Science, 79, 1693-1698. http://dx.doi.org/10.3168/jds.S0022-0302(96)76534-7

[19] Estepar, J., Sánchez, M.M., Alonso, L. and Mayo, B. (1999) Biochemical and Microbiological Characterization of Artisanal "Peñamellera" Cheese: Analysis of Its Indigenous Lactic Acid Bacteria. International Dairy Journal, 9, 737 746. http://dx.doi.org/10.1016/S0958-6946(99)00141-7

[20] López, S. and Mayo, B. (1997) Identification and Characterization of Homofermentative Mesophilic Lactobacillus Strains Isolated from Artisan Starter-Free Cheeses. Letters in Applied Microbiology, 25, 233-238. http://dx.doi.org/10.1046/j.1472-765X.1997.00197.x

[21] Crow, V., Curry, B. and Hayes, M. (2001) The Ecology of Non-Starter Lactic Acid Bacteria (NSLAB) and Their Use as Adjuncts in New Zealand Cheddar. International Dairy Journal, 11, 275-283. http://dx.doi.org/10.1016/S0958-6946(01)00057-7

[22] Devoyod, J.J. and Lapierre, M.-J. (1969) La flore microbienne du fromage de Roquefort. IV. Les enterocoques. Lait, 49, 637-650. http://dx.doi.org/10.1051/lait:1969489-49024

[23] Ordóñez, J.A., Barneto, R. and Marmol, M.P. (1978) Identificación de la flora que participa en la maduración del queso manchego. Anales de Bromatología, 30, 361-373.

[24] Arizcun, J., Itulain, M., Salmeron, J. and Torre, P. (1996) Estudio de los quesos de la denominación de origen Roncal e Idiazábal fabricados en Navarra. Alimentaria, 274, 69-71.

[25] Zárate, V., Belda, F., Pérez, C. and Cardell, E. (1997) Changes in the Microbial Flora of Tenerife Goat’s Milk Cheese during Ripening. International Dairy Journal, 7, 635-641. http://dx.doi.org/10.1016/S0958-6946(97)00065-4

[26] Feutry, F., Oneca, M., Berthier, F. and Torre, P. (2012) Biodiversity and Growth Dynamics of Lactic Acid Bacteria in Artisanal PDO Ossau-Iraty Cheeses Made from Raw Ewe's Milk with Different Starters. Food Microbiology, 29, 33-42. http://dx.doi.org/10.1016/j.fm.2011.08.011

[27] Wouters, J.T.M., Ayad, E.H.E., Hugenholtz, J. and Smit, G. (2002) Microbes from Raw Milk for Fermented Dairy Products. International Dairy Journal, 12, 91-109. http://dx.doi.org/10.1016/S0958-6946(01)00151-0

[28] Topisirovic, L., Kojic, M., Fira, D., Golic, N., Strahinic, I. and Lozo, J. (2006) Potential of Lactic Acid Bacteria Isolated from Specific Natural Niches in Food Production and Preservation. International Journal of Food Microbiology, 112, 230-235. http://dx.doi.org/10.1016/j.ijfoodmicro.2006.04.009

[29] van Hylckama Vlieg, J.E., Rademaker, J.L., Bachmann, H., Molenaar, D., Kelly, W.J. and Siezen, R.J. (2006) Natural Diversity and Adaptive Responses of Lactococcus lactis. Current Opinion in Biotechnology, 17, 183-190.

[30] Herreros, M.A., Arenas, R., Sandoval, M.H., Castro, J.M., Fresno, J.M. and Tornadijo, M.E. (2007) Effect of Native Cultures on Characteristics of Armada Cheese Manufactured with Pasteurized Milk: A Preliminary Study. International Dairy Journal, 17, 328-335. http://dx.doi.org/10.1016/j.idairyj.2006.04.005

[31] Alegría, A., Álvarez-Martín, P., Sacristán, N., Fernández, E., Delgado, S. and Mayo, B. (2009) Diversity and Evolution of the Microbial Populations during Manufacture and Ripening of Casín, a Traditional Spanish, Starter-Free Cheese Made from Cow's Milk. International Journal of Food Microbiology, 136, 44-51. http://dx.doi.org/10.1016/j.ijfoodmicro.2009.09.023

[32] Cogan, T., Barbosa, M., Beuvier, E., Bianchi-Salvadori, B., Cocconcelli, P.S., Fernández, I., Gómez, J., Gómez, R., Kalantzopoulos, G., Ledda, A., Medina, M., Rea, M.C. and Rodríguez, E. (1997) Characterization of Lactic Acid Bacteria in Artisanal Dairy Products. Journal of Dairy Research, 64, 409-421. http://dx.doi.org/10.1017/S0022029997002185

[33] Beresford, T.P., Fitzsimons, N.A., Brennan, N.L. and Cogan, T.M. (2001) Recent Advances in Cheese Microbiology. International Dairy Journal, 11, 259-274. http://dx.doi.org/10.1016/S0958-6946(01)00056-5

[34] Requena, T., Peláez, C. and Desmazeaud, M.J. (1991) Characterization of Lactococci and Lactobacilli Isolated from Semi-Hard Goat's Cheese. Journal of DairyResearch, 58, 137-145. http://dx.doi.org/10.1017/S0022029900033586

[35] Mas, M. and González Crespo, J. (1992) Bacterias ácido lácticas del queso de los Ibores. Alimentaria, 230, 41-43.

[36] Ayad, E.H.E., Nashat, S., El-Sadek, N., Metwaly, H. and El Soda, M. (2004) Selection of Wild Lactic Acid Bacteria Isolated from Traditional Egyptian Dairy Products According to Production and Technological Criteria. Food Microbiology, 21, 715-725. 
[37] Garabal, J.I., Rodríguez-Alonso, P. and Centeno, J.A. (2008) Characterization of Lactic Acid Bacteria Isolated from Raw Cows' Milk Cheeses Currently Produced in Galicia (NW Spain). LWT-Food Science and Technology, 41, 14521458. http://dx.doi.org/10.1016/j.lwt.2007.09.004

[38] Asteri, I.A., Robertson, N., Kagkli, D.M., Andrewes, P., Nychas, G., Coolbear, T., Holland, R., Crow, V. and Tsakalidou, E. (2009) Technological and Flavour Potential of Cultures Isolated from Traditional Greek Cheeses-A Pool of Novel Species and Starters. International Dairy Journal, 19, 595-604. http://dx.doi.org/10.1016/j.idairyj.2009.04.006

[39] Herreros, M.A., Fresno, J.M., González Prieto, M.J. and Tornadijo, M.E. (2003) Technological Characterization of Lactic Acid Bacteria Isolated from Armada Cheese (a Spanish Goats’ Milk Cheese). International Dairy Journal, 13, 469-479. http://dx.doi.org/10.1016/S0958-6946(03)00054-2

[40] González, L., Sacristán, N., Arenas, R., Fresno, J.M. and Tornadijo, M.E. (2010) Enzymatic Activity of Lactic Acid Bacteria (with Antimicrobial Properties) Isolated from a Traditional Spanish Cheese. Food Microbiology, 27, $592-597$. http://dx.doi.org/10.1016/S0958-6946(03)00054-2

[41] Mayo, B., Hardison, C. and Braña, A.F. (1990) Characterization of Wild Strains of Lactococcus lactis subsp. Lactis Isolated from Cabrales Cheese. Journal of Dairy Research, 57, 125-134. http://dx.doi.org/10.1017/S0022029900026686

[42] Centeno, J.A., Cepeda, A. and Rodríguez Otero, J.L. (1996) Lactic Acid Bacteria Isolated from Arzúa Cow’s Milk Cheese. International Dairy Journal, 6, 65-78. http://dx.doi.org/10.1016/0958-6946(96)80001-X

[43] Menéndez, S., Centeno, J.A., Godínez, R. and Rodríguez-Otero, J.L. (1998) Algunas propiedades tecnológicas y actividades enzimáticas de cepas de Enterococcus faecalis aisladas del queso del Cebreiro. Alimentaria, 98, 71-76.

[44] González Arias, L., Fernández, D., Sacristán, N., Arenas, R., Fresno, J.M. and Tornadijo, E. (2013) Enzymatic Activity, Surface Hydrophobicity and Biogenic Amines Production in Lactic Acid Bacteria Isolated from an Artisanal Spanish Cheese. African Journal of Microbiology Research, 7, 2114-2118.

[45] Gill, C. and Rowland, I. (2002) Diet and Cancer: Assessing the Risk. British Journal of Nutrition, 88, 73-87. http://dx.doi.org/10.1079/BJN2002632

[46] Tanner, A.C., Strzempko, M.N., Belsky, C.A. and McKinley, A.G. (1985) API ZYM and API An-Ident Reactions of Fastidious Oral Gram-Negatives Species. Journal of Clinical Microbiology, 22, 333-335.

[47] Tzanetakis, N. and Litopoulou-Tzanetaki, E. (1989) Lactic Acid Bacteria in Raw Goat Milk and Some of Their Biochemical Properties. Microbiology, Aliments and Nutrition, 7, 13-80.

[48] Menéndez, S., Godínez, R., Centeno, J.A. and Rodríguez-Otero, J.L. (2001) Microbial, Chemical and Biochemical Characteristics of “Tetilla” Raw Cows-Milk Cheese. Food Microbiology, 18, 151-158.

http://dx.doi.org/10.1006/fmic.2000.0385 